\title{
Correlation of Hop Stunt Viroid Variants to Cachexia and Xyloporosis Diseases of Citrus
}

\author{
K. Reanwarakorn and J. S. Semancik
}

Department of Plant Pathology, University of California, Riverside 92521.

Current address of K. Reanwarakorn: Department of Plant Pathology, Kasetsart University, Kamphaengsaen, Nakorn Pathom, 73140, Thailand. Accepted for publication 18 March 1999.

\begin{abstract}
Reanwarakorn, K., and Semancik, J. S. 1999. Correlation of hop stunt viroid variants to cachexia and xyloporosis diseases of citrus. Phytopathology 89:568-574.

Citrus viroid (CVd) group II is comprised of hop stunt viroid (HSVd)related variants of 295 to 302 nucleotides. Included in this group are the cachexia-inducing agents citrus cachexia viroid (or CVd-IIb), CVd-IIc, Ca-903, and Ca-909 as well as the non-cachexia-inducing variant CVd-IIa. The cachexia indexing hosts 'Parson's Special' mandarin and 'Orlando' tangelo as well as Citrus macrophylla responded with symptoms of gumming, discoloration, and stem pitting when infected by CVd-IIb, CVd-IIc,

or Ca-903. However, 'Palestine' sweet lime, the indicator host used to describe the xyloporosis disease, displayed a distinctly different fine-pitting reaction and no discoloration or gumming when infected by the same viroids. Cachexia-inducing variants contain a number of nucleotide changes more similar to hop-type HSVd sequences than to the citrus-type HSVd sequences, as typified by CVd-IIa. The nucleotide sequence of CVd-IIc was identical to CVd group II isolates common to trees expressing $\mathrm{xy}-$ loporosis. Experimental evidence indicates that either CVd-IIb or CVdIIc can cause citrus diseases known as cachexia and xyloporosis and that the two disease designations reflect the distinct responses of different indexing hosts to the same viroids.
\end{abstract}

Viroids are the smallest known pathogenic agents of plants and consist of a nontranslated, single-stranded, circular RNA of 246 to 399 nucleotides (8). Citrus viroids (CVds) have been classified on the basis of physical and biological properties into five groups of viroid variants with genomes that range from 284 to 375 nucleotides (7).

The group II CVds contain hop stunt viroid (HSVd)-related variants including CVd-IIa, CVd-IIb, and CVd-IIc (5,6,14,29,31, $35,40)$. CVd-IIb was identified as citrus cachexia viroid (CCaVd) and induced severe gumming, discoloration, and stem-pitting symptoms on the indexing host 'Parson's Special' mandarin (PSM) (37); whereas infection by CVd-IIa, identical to HSVd-citrus variant 1 (29), produced no symptoms on the same host (38). The smallest of the group II viroids, CVd-IIc, was isolated from trees with cachexia disease in California and is common to xyloporosis disease sources from Israel (34).

Cachexia was described as a virus-induced, transmissible disease in 'Orlando' tangelo (OT) by Childs $(2,4)$. Xyloporosis was reported as a disease of 'Palestine' sweet lime (PSL) attributed to either physiological factors by Reichert and Perlberger (24) or an incompatibility between rootstock and scion by Moreira (15). On the basis of symptom similarity and pathological anatomy, Childs (3) suggested that xyloporosis and cachexia were the same disease. The relationship between the two diseases remained unresolved with divergent interpretations of host reactions as affected by rootstock-scion combinations and environmental factors $(10,23)$.

More than 30 years later, Roistacher (25) indicated that the transmission of the xyloporosis agent had never been accomplished and that transmission of the cachexia agent to sweet lime failed to reproduce the symptoms of xyloporosis. Therefore, it was suggested

Corresponding author: J. S. Semancik; E-mail address: semancik@ucrac1.ucr.edu

Publication no. P-1999-0414-01R

(C) 1999 The American Phytopathological Society that cachexia should be considered a specific viroid-induced disease characterized by a specific response on PSM and that the term xyloporosis be used to describe the condition originally described in sweet lime (24) with factors other than the cachexia viroid involved.

Uncertainties in nomenclature persist, with the terms xyloporosis and cachexia used either interchangeably as a common condition or to describe what were considered to be different diseases. Although cachexia and xyloporosis diseases have been recognized for more than 50 years, no definitive experimental data has been presented to determine the relationship between the two diseases. Experimental data from nucleotide sequence homology for selected HSVd-related variants as well as comparative reactions on indexing hosts is presented that clarifies the relationship between cachexia and xyloporosis.

\section{MATERIALS AND METHODS}

Viroid sources. The CVd group II variants, CVd-IIa, CVd-IIb, CVd-IIc, Ca-903, and Ca-909, were selected from the University of California-Riverside (UCR) viroid collection. Xyloporosis disease sources from Israel were kindly provided by M. Bar-Joseph. Three xyloporosis sources, previously analyzed by sequential polyacrylamide gel electrophoresis (sPAGE) contained a common CVdIIc component (34).

These sources were bioamplified by inoculation to citron (Citrus medica L.) for further physical characterization, as well as to provide a tissue source for graft inoculation of indexing host plants. Nucleotide sequence stability and biological activity in different hosts from diverse botanical families has been well documented as a characteristic of HSVd variants $(13,21,22)$.

Citrus indicator hosts. Cachexia bioassay was accomplished by inoculation of clonally propagated PSM grafted to rough lemon rootstock (1). Plants were kept at elevated glasshouse temperatures $\left(28\right.$ to $38^{\circ} \mathrm{C}$ ) for 1 year to promote cachexia-positive symptom expression of browning and gumming at the bud union. 
To further assist in the resolution of the relationship between the cachexia and xyloporosis diseases, seedlings of four additional citrus indicators known to react with either disease were also inoculated. These included OT (C. paradisi Macfad. $\times C$. reticulata Blanco), the classical indexing host for cachexia (3); PSL (C. aurantifolia (L.) Swingle), the indexing host for xyloporosis (24); C. macrophylla P.J. Wester (CM); and 'Rangpur' lime (RL) (C. limonia Osbeck) $(17,26)$. Seedlings were budded with grapefruit $(C$. paradisi), which served as a vigorous scion to promote more rapid growth and development of the symptoms on the rootstock.

After 1 year under glasshouse conditions, tissue pieces were taken from the grapefruit scions and used for inoculation to citron to verify infection and determine the nucleotide sequence of the viroid progeny in the different indexing hosts. Trees were maintained under standard field conditions for an additional 2 years before evaluating the development of symptoms by removing bark on the rootstock. Indicator trees were removed from the field after 4 years, and the bark was peeled from 1 foot above and below the graft union for final evaluation of symptoms.

Nucleic acid extraction and viroid identification. Viroid-enriched nucleic acids were purified from citron by the method of Semancik et al. (38). The viroid RNAs were characterized by SPAGE (36) and reverse-transcriptase polymerase chain reaction (RT-PCR) amplification. Viroid RNAs were amplified by RT-PCR $(27,40)$ using two pairs of primers constructed from the sequence of CVd-IIa, which react with all of the CVd group II variants em-

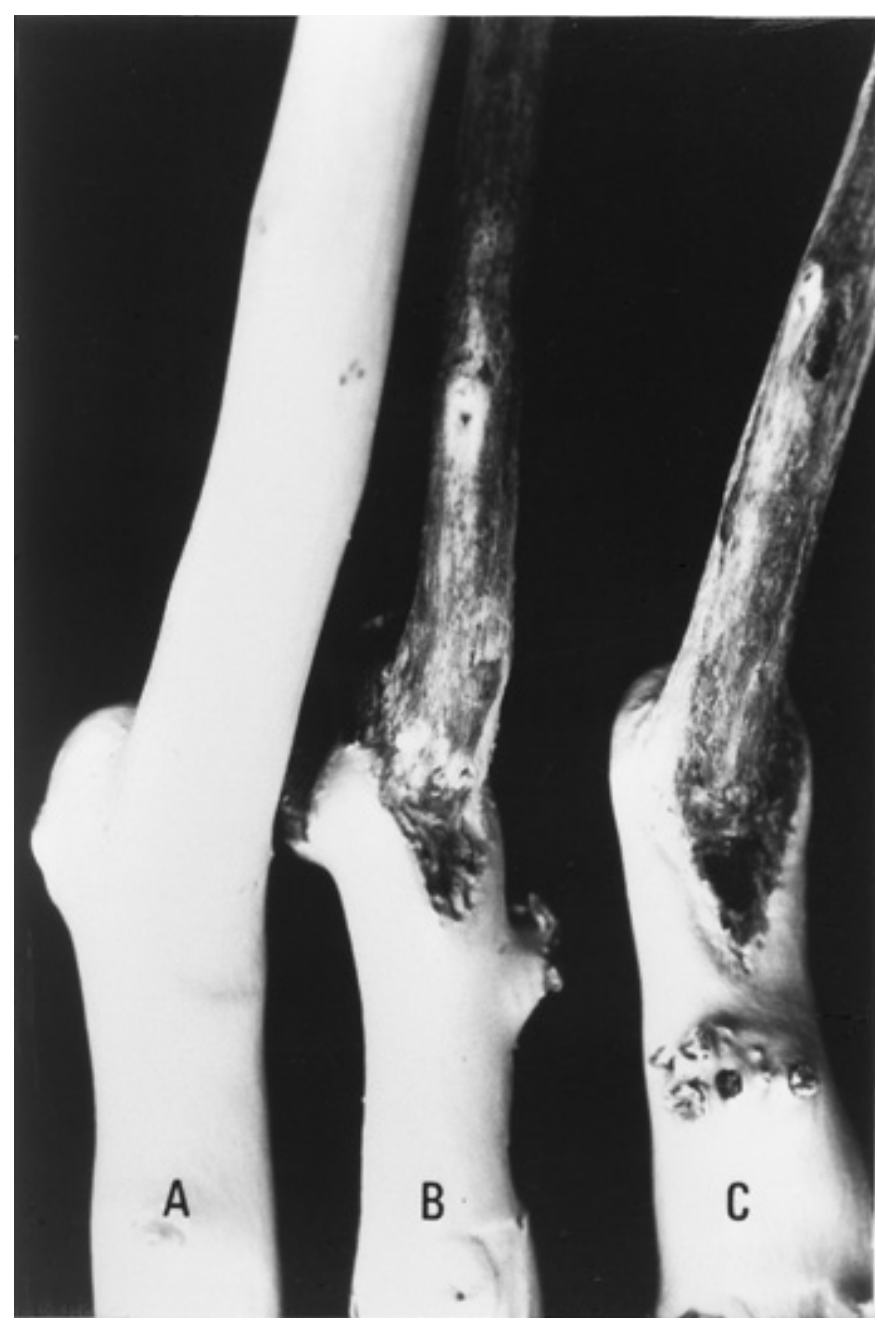

Fig. 1. Reaction of citrus viroid (CVd) group II variants on 'Parson's Special' mandarin scion budded on rough lemon rootstock. $\mathbf{A}, \mathrm{CVd}-\mathrm{II} a$ demonstrates no cachexia symptoms, while $\mathbf{B}, \mathrm{CVd}-\mathrm{IIb}$ and $\mathbf{C}, \mathrm{CVd}-\mathrm{II}$ show strong cachexia symptoms. ployed here: (i) cDNA 625 (5'GTTGCCCCGGGGCTCCT3') \#7288 and hDNA 1394 (5'TCTTCTCAGAATCCAGCG3') \#89-106; and (ii) IICI (5'CTGGATCCGCGGCAGAGGCT3') \#271-288 and IIHI (5'CCGGATCCTCTCTTGAGCCCCT3') \#283-302. PCR products were purified by phenol purification (27) and sequenced by the dideoxy chain termination technique (28) using the 'fmol' procedure (Promega Corp., Madison, WI). Analysis of the standardized progeny viroid titer from citron by 'fmol' provided an indication of population diversity rather than individual clones from the various hosts employed.

Computer analysis. Nucleotide sequences of the UCR group II $\mathrm{CVds}$ were compared with published sequences of CVd group II variants as well as other viroids included in the HSVd family by the sequence analysis program GAP at a gap-weight of 5.0 and a gap-length-weight of 0.30 . The multiple sequence alignment method described by Higgins and Sharp (11) in the PileUp program was employed for homology relationships (Genetic Computer Group, Inc., Madison, WI).

\section{RESULTS}

Indexing of CVd group II variants for cachexia. After a 1-year incubation period under high-temperature glasshouse conditions, the cachexia indicator PSM was evaluated for symptoms of discoloration and gumming concentrated above the bud union with the rough lemon rootstock and pitting throughout the PSM scion (Fig. 1). CVd-IIa-infected PSM tissues were identical to the uninoculated controls; whereas the cachexia-inducing variants produced a range of symptoms (Table 1). Similar severe responses resulted from infection by either CVd-IIb or CVd-IIc. A more moderate reaction was induced by $\mathrm{Ca}-903$, while inoculation with $\mathrm{Ca}-909$ resulted in the mildest symptoms.

Differential response of citrus indicators to $\mathrm{CVd}$ group II variants. Indexing hosts were removed after 4 years in the field (5 years postinoculation), and symptoms at the graft union were evaluated (Fig. 2). All plant materials containing CVd-IIa remained indistinguishable from the uninoculated controls. The cachexia-positive variants induced symptoms with a range of severity on the various indicators (Table 1). CVd-IIb and CVd-IIc induced similar severe reactions on all indexing hosts. With the exception of the severe reaction on OT, Ca-903 induced more moderate symptoms. In striking contrast to the other CVd group II cachexia variants, Ca-909 induced only very mild reactions on PSL, OT, and PSM, with no symptoms induced on RL and CM.

An obvious qualitative distinction in the symptom reaction was noted that segregated the indicators into two classes. PSM, OT, and $\mathrm{CM}$ displayed symptoms of discoloration and gumming at the bud union and extensive stem pitting (Fig. 2A and C). In contrast, even in the presence of severe stem pitting, PSL and RL showed no discoloration or gumming reaction (Fig. 2B and D). In addi-

TABLE 1. Symptom severity of citrus indicators to noncachexia- (CVd-IIa) and cachexia-inducing group II citrus viroids

\begin{tabular}{|c|c|c|c|c|c|}
\hline Symptoms/cultivars ${ }^{\mathrm{a}}$ & \multicolumn{2}{|c|}{ CVd-IIa CVd-IIb } & CVd-IIc & Ca-903 & $\mathrm{Ca}-909$ \\
\hline Fine stem pitting & & & & & \\
\hline 'Palestine' sweet lime & $-{ }^{\mathrm{b}}$ & ++++ & ++++ & +++ & + \\
\hline Coarse stem pitting & & & & & \\
\hline 'Rangpur' lime & - & +++ & ++ & ++ & - \\
\hline Stem pitting + discoloration, & & & & & \\
\hline 'Orlando' tangelo & - & ++++ & +++ & ++++ & + \\
\hline Citrus macrophylla & - & +++ & ++++ & ++ & - \\
\hline 'Parson's Special' mandarin & - & ++++ & ++++ & ++ & + \\
\hline
\end{tabular}

a Symptom severity from average of four plants after 4 years of growth under field conditions in Riverside, CA, for 'Palestine' sweet lime, 'Rangpur' lime, 'Orlando' tangelo, and Citrus macrophylla. Consensus symptom severity from two sets of 'Parson's Special' mandarin indicator plants (six per treatment) after 8 to 12 months in a greenhouse with elevated temperatures $\left(28\right.$ to $\left.38^{\circ} \mathrm{C}\right)$.

b Relative severity: $-=$ no reaction to $++++=$ severe symptoms. 
tion, the pitting observed in PSL was finer than in any of the other indicators (Fig. 2B).

Nucleotide sequence comparison among CVd group II variants. The nucleotide sequences of CVd group II variants purified from citron tissue inoculated with the primary isolates ranged between 295 to 302 nucleotides. The sole noncachexia isolate in the UCR collection, the 302-nucleotide CVd-IIa (GenBank accession no. AF131248), differed from the HSVd-citrus variant 1 (29) by only two exchanges at nucleotide $153(\mathrm{U} \rightarrow \mathrm{A})$ and $270(\mathrm{~A} \rightarrow \mathrm{G})$. The cachexia-inducing isolates CVd-IIb (GenBank accession no. AF131249), CVd-IIc (GenBank accession no. AF131250), Ca-903 (GenBank accession no. AF131251), and Ca-909 (GenBank accession no. AF131252) varied in size between 295 to 299 nucleotides (Fig. 3).

The most recurrent distinction between CVd-IIa and the cachexiainducing variants was the common cluster of six nucleotide changes in the variable $(\mathrm{V})$ domain and the single deletion $(-\mathrm{A})$ in the terminal (T2) domain found in three of the four cachexia variants analyzed (22). The exception, Ca-909, registered unusually mild cachexia reactions; however, it shares changes at nucleotides 207 $(+\mathrm{C})$ and $209(-\mathrm{G})$ with the severe variants CVd-IIb and CVd-IIc, as well as the deletion (-UUC) at nucleotides 245 to 247 with CVd-IIc. The only other nucleotide distinction from the noncachexia variant $\mathrm{CVd}$-IIa common to at least two cachexia variants was at nucleotide $26(\mathrm{G} \rightarrow \mathrm{A})$, as found in CVd-IIb and CVd-IIc. Several of these nucleotide exchanges featured in the cachexia variants, as highlighted in Figure 3, represent changes from the citrustype HSVd sequence, as found in CVd-IIa, to the hop-type HSVd sequence $(13,30)$.

After 2 years of infection, replicate tissue samples were taken from the grapefruit scions of field trees budded to the citrus indicators OT, PSL, and CM rootstocks and used to inoculate citron seedlings. The nucleotide sequence from progeny viroid of $\mathrm{CVd}$ IIa and CVd-IIb from all indicators remained stable with 302 and 299 nucleotides, respectively; while CVd-IIc progeny from OT and PSL were modified by only a single addition of $+\mathrm{A}$ at nucleotide position 153 .
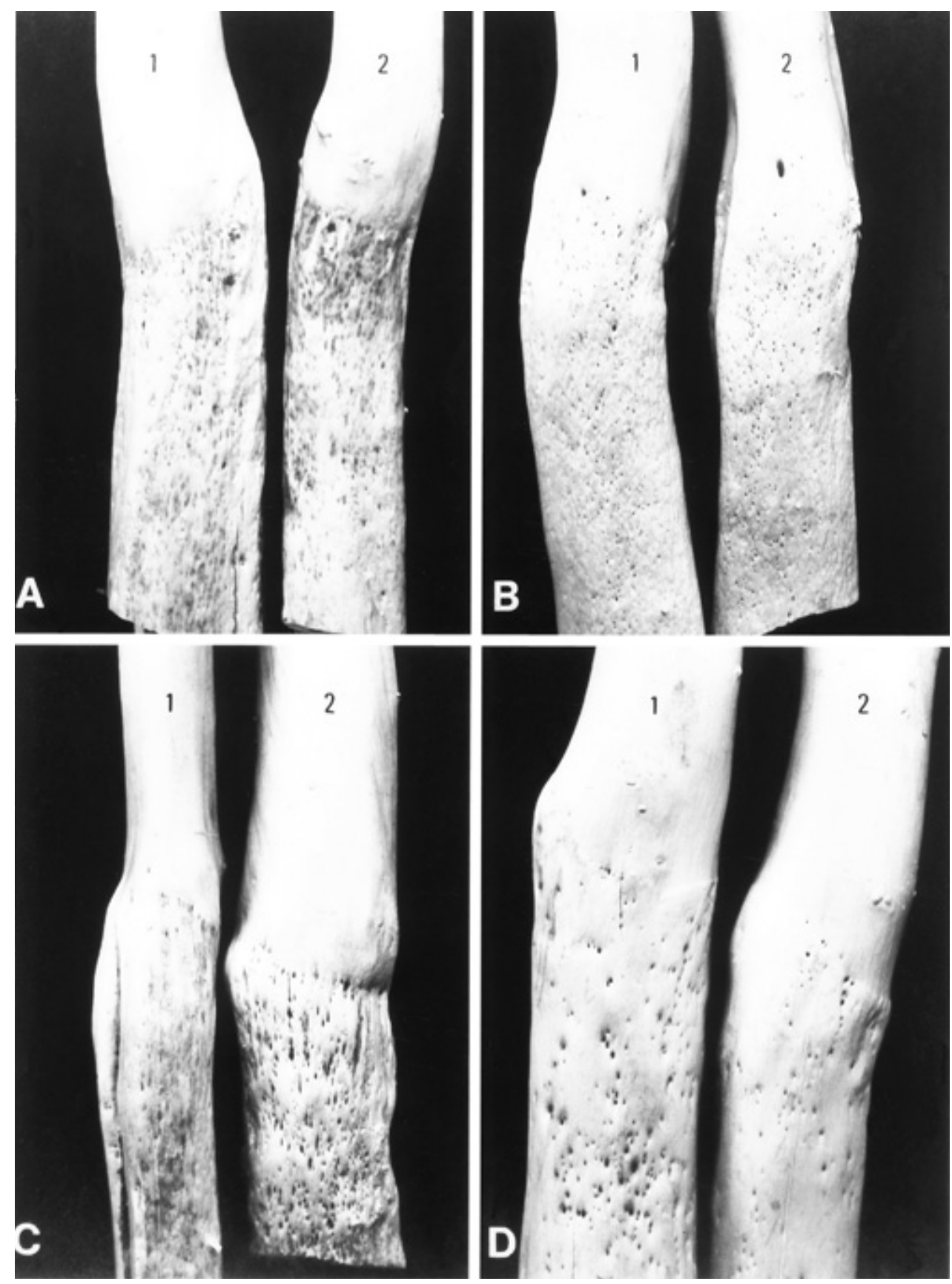

Fig. 2. Symptom expression of CVd-IIb (1) and CVd-IIc (2) on A, 'Orlando' tangelo; B, 'Palestine' sweet lime; C, Citrus macrophylla; and D, 'Rangpur' lime. Note stem pitting on all hosts, but gumming and discoloration only on 'Orlando' tangelo and Citrus macrophylla. 
The nucleotide sequence of the CVd-IIc-like variant common to the three xyloporosis sources from Israel (34) was found to be $295 \mathrm{nu}-$ cleotides and identical to the CVd-IIc variant originally isolated from cachexia disease samples in California.

Group II CVds as variants of HSVd. The nucleotide sequences of CVd-IIa and CVd-IIb as characteristic noncachexia and cachexia group II variants tested here were compared for sequence homology to previously reported hop stunt variants. Both variants reflected the conserved sequence homology of 92.5 to $99.3 \%$, characteristic of the HSVd family.

The PileUp program analysis of published CVd group II sequences produced a clustering of closely related variants into plum-,
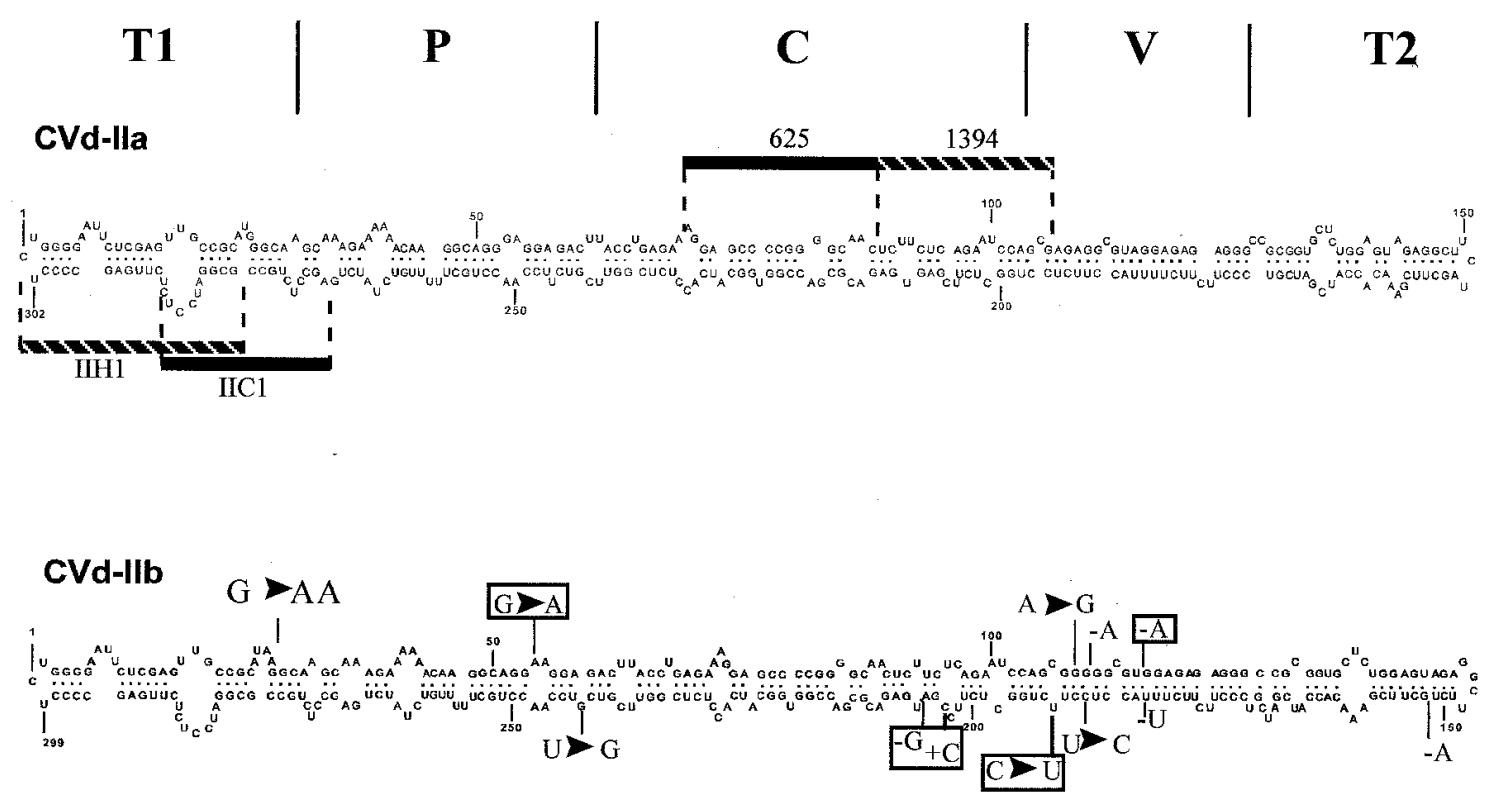

\section{CVd-Ilc}

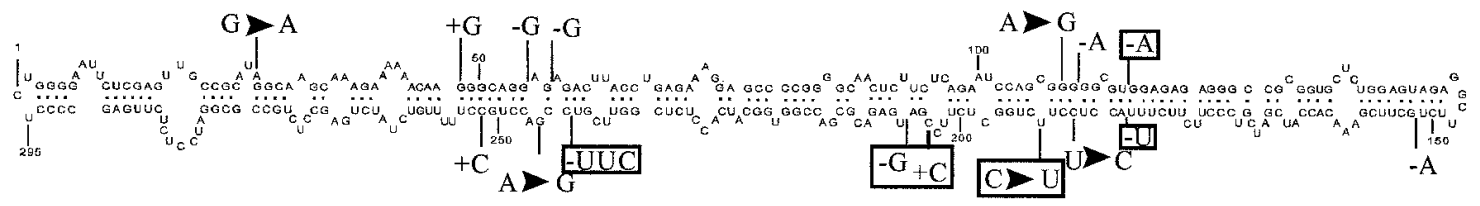

\section{Ca-903}

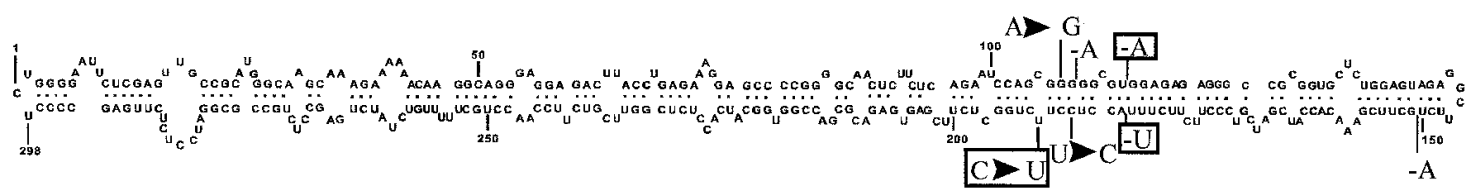

\section{Ca-909}

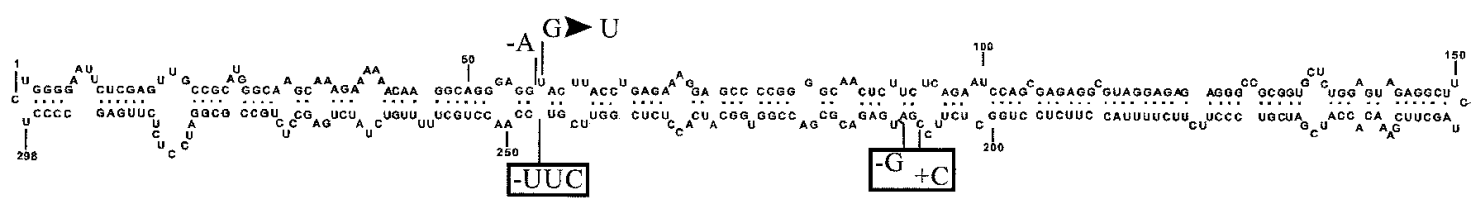

Fig. 3. Nucleotide sequences of noncachexia-inducing variant CVd-IIa and cachexia-inducing variants CVd-IIb, CVd-IIc, Ca-903, and Ca-909. Nucleotide changes from CVd-IIa in cachexia variants are indicated, as well as those representing changes from citrus-type to hop-type hop stunt viroid sequences (boxed). Position of primers and viroid domains noted. 
citrus-, and hop-type HSVd sequences (30) as presented in Figure 4. When this relationship was correlated with cachexia disease induction, variants that induce cachexia were found in three of the six clusters. The cachexia variants aligned in two subgroups, both of them hop-type HSVd sequences (Fig. 4C-1 and C-3). Only the mild cachexia variant, Ca-909, and the non-cachexia-inducing or untested variants were identified in the citrus-type HSVd group (Fig. 4B). The bulk of the variants that have not been indexed for HSVd group (Fig. 4C-2), along with variants from peach and grapevine. cachexia were clustered as a distinct subgroup of the hop-type

\section{DISCUSSION}

Variations among cachexia-inducing variants. $\mathrm{CVd}-\mathrm{IIb}$ has been designated as $\mathrm{CCaVd}$, the type cachexia viroid $(37,38)$. All cachexia-inducing variants, CVd-IIb, CVd-IIc, Ca-903, and Ca909, displayed the characteristic symptoms of stem pitting and gumming on PSM. It is unclear whether other members of the HSVd family have ever been tested on this indexing host (39).

The effect of cachexia variants on indexing hosts such as PSM can be seriously moderated by the presence of a mixed infection. Thus, the severe reaction induced by $\mathrm{CVd}-\mathrm{IIb}$ was markedly re-

\section{Cachexia Reference \\ Reaction Number}

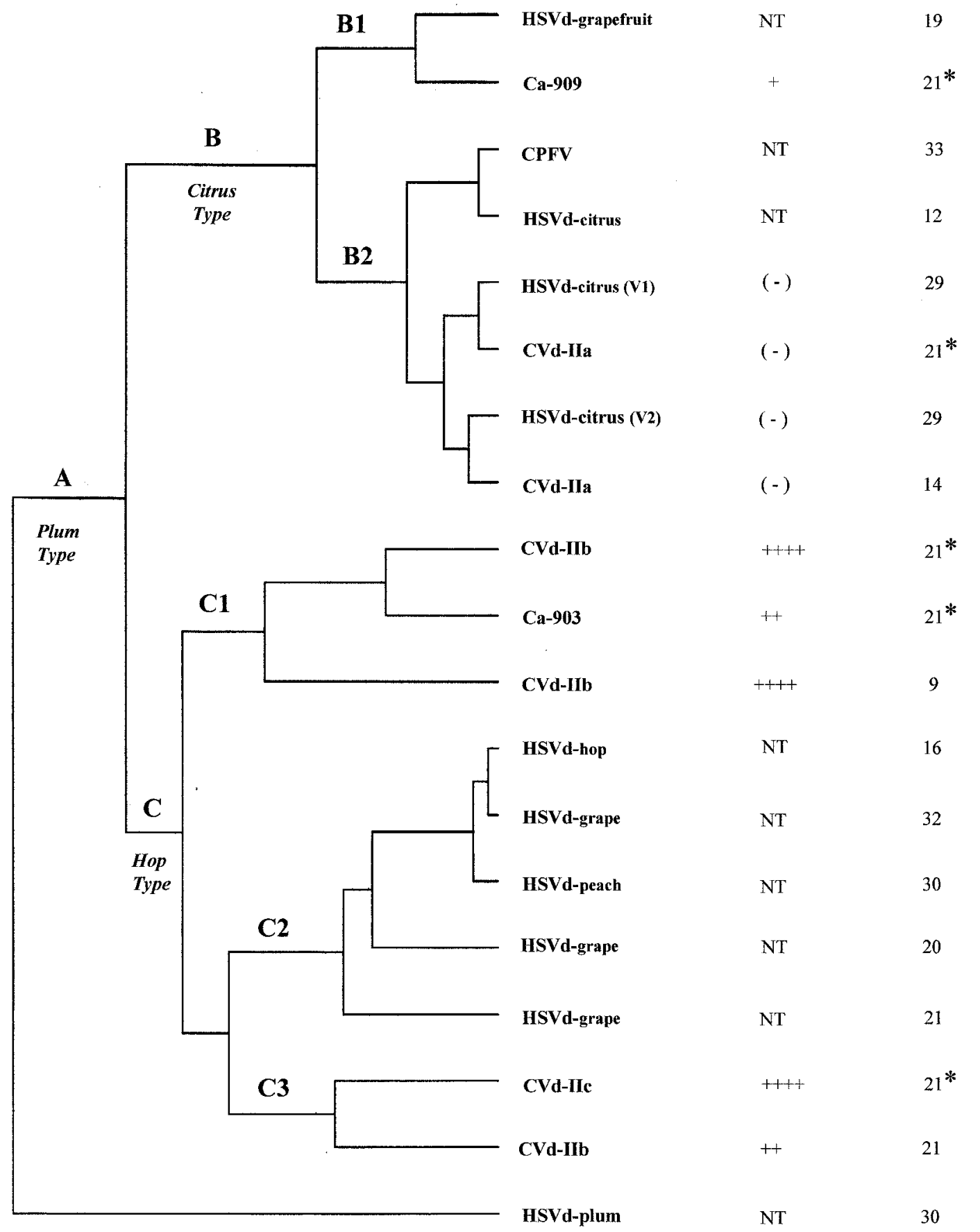

Fig. 4. Dendrogram of hop stunt viroid (HSVd) variants determined from published sequences by using multiple sequence alignment method described by Higgins and Sharp (11) in the PileUp program of the Genetic Computer Group. Grouping of HSVd variants designated as A, plum-type; B, citrus-type; and C, hop-type groups. Variants of CVd-IIa, CVd-IIb, and CVd-IIc used in this study are indicated $(*)$. 
duced by "viroid interference" in the presence of CVd-IIa $(18,35)$. As a result, some of the reactions previously attributed to cachexia isolates may have been the result of using poorly characterized graft-transmissible agents containing a mixture of variants.

Relationship of CVd group II variants to HSVd sequence diversity. The sizes of a collection of group II CVds were estimated by the sPAGE method as ranging from 297 to 302 bases (34). With the addition here of the sequence of CVd-IIc, the lower limit of this group has been extended to 295 nucleotides. CVd-IIc, as well as variants of similar size (294 to 295 nucleotides) characterized from Prunus and grapevine sources (13), are included in the hop-type HSVd group. As anticipated from the highly conserved nature of viroids in the HSVd family, the citrus viroids were found to be closely related in size and sequence homology to HSVd variants found in a diverse collection of woody and herbaceous hosts (297 to 303 nucleotides) $(13,30)$. The non-cachexiainducing isolate CVd-IIa displays a similar sequence homology of 99.34\% with both the HSVd-citrus variant 1 (29) as well as with HSVd-cit (12).

The dendrogram (Fig. 4) for the CVd group II variants, as well as other reported HSVd variants, displayed the three major groups designated as plum-type, citrus-type, and hop-type HSVd groups. Within the citrus-type group are the non-cachexia variant CVd-IIa and other closely related citrus variants differing by only a few nucleotides. The single cachexia-inducing variant in this group, Ca-909, induces only mild symptoms.

Although most of the variants clustered within the citrus-type group have not been tested on PSM, based on the relationship highlighted in the dendrogram, a negative bioassay reaction would be predicted. The Ca-909 variant that induces mild cachexia disease symptoms shares fewer common features of nucleotide sequence with the other cachexia-positive variants. This distinction is especially true for the six-nucleotide cluster in the $\mathrm{V}$ domain previously identified as essential for the induction of cachexia disease by CVd-IIb (22). The ability of Ca-909 to incite cachexia symptoms indicates that nucleotide sequence is not the sole factor regulating the expression of biological activity in viroid infection. In effect, this could be a possible demonstration of the equivalence of biological activity of viroids by conformational homology derived from dissimilar nucleotide sequences.

It is interesting that the bulk of the cachexia-inducing variants are contained within the hop-type grouping (Fig. 4C-1 and C-3) by virtue of sequence changes or reversions from the presumed progenitor citrus-type HSVd sequence. A significant number of these changes occur within the $\mathrm{V}$ domain cluster of six nucleotides identified as the locus controlling cachexia infectivity (22). Bracketed between these two groupings within the hop-type cluster is a group of variants derived from hop, grapevine, and peach (Fig. 4C-2) that have not been indexed for cachexia. It is tempting to predict from this clustering that this group could induce cachexia.

Definition of cachexia and xyloporosis diseases of citrus. An essentially identical range of symptoms were produced by $\mathrm{CVd}$ IIb and CVd-IIc in the citrus indicators PSM, PSL, OT, CM, and RL. Especially significant was the fact that both CVd-IIb and $\mathrm{CVd}$-IIc caused an unusual reaction of fine stem pitting in the absence of gumming in PSL. Thus, the reported distinctions between xyloporosis and cachexia (25) could not be supported. It is concluded that the same disease symptoms can be induced by either CVd-IIb or CVd-IIc in comparable indicator citrus species, even though they differ in nucleotide number and sequence.

This interpretation, supported by experimental data with defined causal agents, confirms historical observations by Childs (4) for distinctions in cachexia and xyloporosis as the distinct responses of OT and sweet lime, and not a difference in the disease-causing agents. A similar interpretation of transmission and common symptom expression made with graft-transmissible agents of unknown composition was proposed by Reichert and Bental (23) and Olson et al. (17). The experimental evidence offered here with purified stable viroid variants supports these early observations and suggests coidentity of the cachexia and xyloporosis diseases.

The data reported here indicate that both $\mathrm{CVd}$-IIb or the type CCaVd and CVd-IIc produced cachexia-type symptoms on OT and xyloporosis-type symptoms on PSL. Since the nucleotide sequence of CVd-IIc is identical to that of the three xyloporosis isolates, it may be suggested as the most common CVd group II variant of the group II CVds inducing xyloporosis.

In deference to historical precedent and the data presented here, the term "cachexia" is an accurate description of the viroid-induced disease of tangelos and mandarins as characterized by indexing on PSM and could be used for the fine-pitting reaction on PSL. The term "xyloporosis" can be retained as a descriptive term for the specific reaction to the cachexia viroids on PSL.

\section{ACKNOWLEDGMENTS}

These studies were supported, in part, by grants from the California Citrus Research Board. We thank D. J. Gumpf for helpful discussions and J. Bash, J. A. Szychowski, and E. de Jager-O'Shea for excellent support in portions of this study. Material presented here was submitted for partial fulfillment for the Ph.D. degree by K. Reanwarakorn. Support of the Government of Thailand to K. Reanwarakorn is gratefully appreciated.

\section{LITERATURE CITED}

1. Calavan, E. C., and Christiansen, D. 1985. Variability of cachexia reaction among varieties of rootstocks within clonal propagations of citrus. Pages 76-85 in: Proc. Conf. Int. Organ. Citrus Virol., 3rd. IOCV, Riverside, CA.

2. Childs, J. F. L. 1950. The cachexia disease of Orlando tangelo. Plant Dis. Rep. 34:295-298.

3. Childs, J. F. L. 1952. Cachexia disease, its bud transmission and relation to xyloporosis and to tristeza. Phytopathology 42:265-268.

4. Childs, J. F. L. 1956. Transmission experiments and xyloporosiscachexia relations in Florida. Plant Dis. Rep. 40:143-145.

5. Davino, M., Pelicani, L., Renis, M., and Albanese, G. 1991. Homology of hop stunt viroid with citrus cachexia viroid. Pages 196-201 in: Proc. Conf. Int. Organ. Citrus Virol., 11th. IOCV, Riverside, CA.

6. Diener, T. O., Smith, D. R., Hammond, R. H., Albanese, G., La Rosa, R., and Davino, M. 1988. Citrus B viroid identified as a strain of hop stunt viroid. Plant Dis. 72:691-693.

7. Duran-Vila, N., Roistacher, C. N., Rivera-Bustamante, R., and Semancik, J. S. 1988. A definition of citrus viroid groups and their relationship to the exocortis disease. J. Gen. Virol. 69:3069-3080.

8. Flores, R., Randles, J. W., Bar-Joseph, M., and Diener, T. O. 1998. A proposed scheme for viroid classification and nomenclature. Arch. Virol. 143:623-629.

9. Francis, M. I., Szychowski, J. A., and Semancik, J. S. 1995. Structural sites specific to citrus viroid groups. J. Gen. Virol. 76:1081-1089.

10. Grant, T. J., Grimm, G. R., and Norman, P. 1959. Symptom of cachexia in Orlando tangelo, none in sweet lime and false symptoms associated with purple scale infestation. Plant Dis. Rep. 43:1277-1279.

11. Higgins, D. G., and Sharp, P. M. 1989. Fast and sensitive multiple sequence alignments on a microcomputer. CABIOS (Comput. Appl. Biosci.) 5:151-153

12. Hsu, Y.-H., Chen, W., and Owens, R. A. 1994. Nucleotide sequence of a hop stunt viroid variant isolated from citrus growing in Taiwan. Virus Genes 9:193-195.

13. Kofalvi, S. A., Marcos, J. F., Canizares, M. C., Pallas, V., and Candresse, T. 1997. Hop stunt viroid (HSVd) sequence variants from Prunus species: Evidence for recombination between HSVd isolates. J. Gen. Virol. 78:3177-3186.

14. Levy, L., and Hadidi, A. 1993. Direct nucleotide sequencing of PCRamplified DNAs of the closely related citrus viroids IIa and IIb (cachexia). Pages 180-186 in: Proc. Conf. Int. Organ. Citrus Virol., 12th. IOCV, Riverside, CA.

15. Moreira, S. 1938. Xyloporosis. Hadar 11:234-237.

16. Ohno, T., Takamatsu, N., Meshi, T., and Okada, Y. 1983. Hop stunt viroid: Molecular cloning and nucleotide sequence of the complete cDNA copy. Nucleic Acids Res. 11:6185-6187.

17. Olson, E. O., Shull, A., and Buffington, G. 1961. Evaluation of indicators for xyloporosis and exocortis in Texas. Pages 159-165 in: Proc. Conf. Int. Organ. Citrus Virol., 2nd. University of Florida Press, Gainesville.

18. Pina, J. A., Duran-Vila, N., and Navaro, L. 1991. Interference of citrus viroids with cachexia symptoms on Parson's Special mandarin. Pages 206208 in: Proc. Conf. Int. Organ. Citrus Virol., 11th. IOCV, Riverside, CA. 
19. Puchta, H., Ramm, K., Hadas, R., Bar-Joseph, M., Luckinger, R., Freimuller, K., and Sanger, H. L. 1989. Nucleotide sequence of a hop stunt viroid (HSVd) isolate from grapefruit in Israel. Nucleic Acids Res. 17:1247.

20. Puchta, H., Ramm, K., and Sanger, H. L. 1988. Nucleotide sequence of hop stunt viroid isolate from the German grapevine cultivar 'Riesling'. Nuclei Acids Res. 16:2730.

21. Reanwarakorn, K. 1997. Molecular Basis for the Cachexia Disease Syndrome of Citrus. Ph.D. dissertation. University of California-Riverside, Riverside.

22. Reanwarakorn, K., and Semancik, J. S. 1998. Regulation of pathogenicity in hop stunt viroid-related group II citrus viroids. J. Gen. Virol. 79: 3163-3172.

23. Reichert, I., and Bental, A. 1961. On the problem of xyloporosis and cachexia diseases of mandarins. Plant Dis. Rep. 45:356-361.

24. Reichert, I., and Perlberger, J. 1934. Xyloporosis, the new citrus disease. Agric. Exp. Stn. Rehovoth Palestine Bull. 12:49.

25. Roistacher, C. N. 1988. The cachexia and xyloporosis diseases of citrus: A review. Pages 116-123 in: Proc. Conf. Int. Organ. Citrus Virol., 10th. IOCV, Riverside, CA.

26. Salibe, A. A. 1965. A quick field test for xyloporosis virus. Pages 95-98 in: Proc. Conf. Int. Organ. Citrus Virol., 3rd. University of Florida Press, Gainesville.

27. Sambrook, J., Fritsch, E. F., and Maniatist, T. 1989. Molecular Cloning: A Laboratory Manual, 2nd ed. Cold Springs Harbor Laboratory, Cold Springs Harbor, NY.

28. Sanger, F., Coulson, A. R., Barrell, B. G., Smith, A. J., and Roe, B. A. 1980. Cloning in single-strained bacteriophage as an aid to rapid DNA sequencing. J. Mol. Biol. 143:161-178.

29. Sano, T., Hataya, T., and Shikata, E. 1988. Complete nucleotide sequence of a viroid isolated from Etrog citron, a new member of hop stunt group. Nucleic Acids Res. 16:347.

30. Sano, T., Hataya, T., Terai, Y., and Shikata, E. 1989. Hop stunt viroid strains from Dapple fruit disease of plum and peach in Japan. J. Gen. Virol. 70:1311-1319.

31. Sano, T., Kudo, H., Sugimoto, T., and Shikata, E. 1988. Synthetic oligonucleotide hybridization probe to diagnose HSVd strains and CEVd. J. Virol. Methods 19:109-120.

32. Sano, T., Ohshima, T., Hataya, T., Uyeda, I., Shikata, E., Chou, T. G., Meshi, T., and Okada, Y. 1986. A viroid resembling hop stunt viroid in grapevine from Europe, the United States and Japan. J. Gen. Virol. 67: 1673-1678.

33. Sano, T., Uyeda, I., Shikata, E., Ohno, T., and Okada, Y. 1984. Nucleotide sequence of cucumber pale fruit viroid: Homology to hop stunt viroid. Nucleic Acids Res. 12:3427-3433.

34. Semancik, J. S., and Duran-Vila, N. 1991. The grouping of citrus viroids: Additional physical and biological determinants and relationships with diseases of citrus. Pages 178-187 in: Proc. Conf. Int. Organ. Citrus Virol., 11th. IOCV, Riverside, CA.

35. Semancik, J. S., Gumpf, D. J., and Bash, J. A. 1992. Interference between viroids inducing exocortis and cachexia diseases of citrus. Ann. Appl. Biol. 121:577-583.

36. Semancik, J. S., and Harper, R. L. 1984. Optimal conditions for cell-free synthesis of citrus exocortis and the question of specificity of RNA polymerase activity. Proc. Natl. Acad. Sci. U.S.A. 81:4429-4433.

37. Semancik, J. S., Roistacher, C. N., and Duran-Vila, N. 1988. A new viroid is the causal agent of the citrus cachexia disease. Pages 125-135 in: Proc. Conf. Int. Organ. Citrus Virol., 10th. IOCV, Riverside, CA.

38. Semancik, J. S., Roistacher, C. N., Rivera-Bustamante, R., and DuranVila, N. 1988. Citrus cachexia viroid, a new viroid of citrus: Relationship to viroids of the exocortis disease complex. J. Gen. Virol. 69:3059-3068.

39. Shikata, E. 1990. New viroids from Japan. Semin. Virol. 1:107-115.

40. Yang, X., Hadidi, A., and Garnsey, S. M. 1992. Enzymatic cDNA amplification of citrus exocortis and cachexia viroids from infected citrus hosts. Phytopathology 82:279-285. 